\title{
The Medieval Cultural and Political Origins of the Industrial Revolution
}

\author{
Ademar Ribeiro Romeiro ${ }^{1 *}$ \\ ${ }^{1}$ University of Campinas, Brazil \\ *Corresponding author: Ademar Ribeiro Romeiro: arromeiro@gmail.com
}

Citation: Romeiro A.R. (2020) The Medieval Cultural and Political Origins of the Industrial Revolution. Open Science Journal 5(2)

Received: 30th December 2019

Accepted: $4^{\text {th }}$ February 2020

Published: $4^{\text {th }}$ May 2020

Copyright: (C) 2020 This is an open access article under the terms of the Creative Commons Attribution License, which permits unrestricted use, distribution, and reproduction in any medium, provided the original author and source are credited.

Funding: The author(s) received no specific funding for this work

Competing Interests: The author have declared that no competing interests exists.

\begin{abstract}
:
This article argues that cultural and political legacies from the Middle Ages were crucial for the socio-political and economic evolution that led to the Industrial Revolution. The medieval social/political orders had an exceptional openness to innovations (technological, organizational, and institutional) when compared to other contemporary civilizations. An openness resulting from the competition: between them and their multiple organizations independent from the State. The emergence of national states changed the medieval scenario. However, a legacy of some of its essential cultural/institutional features remained and played a decisive role in the forthcoming Industrial Revolution: the Rule of Law, individualism, representative assemblies, the respect for labor and professions (notably the merchants) and the embryo of a culture of economic growth.
\end{abstract}

Keywords: Middle Ages and economic growth, Culture/politics and innovations, Rule of law; Individualism, Democratic governance

\section{Introduction}

The exploration of the origins of the Industrial Revolution (IR) in Europe has generated a long-standing and controversial debate. The criticisms addressed to Landes (1998) last work, were representative of the main controversy divide: the accusation of "Eurocentrism", which means explaining the European success by its unique character signaling superiority. A group of scholars, baptized by Goldstone (2009) as the "Californian school" , proceeded to show that from the beginning of modernity in the XVI century to the end of the XVII, the level of wealth, development, and growth between the two extremes of Eurasia was similar and the supposedly unique character of Western society was the product of the "imagination of Eurocentric historians. It was the "Eurasian similarity thesis." For Perdue (2005), it would be wrong even to point out the competition 
between the European States, something prevailing in other civilizational spaces as well till 1750. Alternatively, as defended by Rosenthal and Wong (2011), the European institutions were not more favorable to economic growth than the Chinese ones, on the contrary. So, if the IR happened to occur in Europe, it was caused by contingent factors such as colonial exploitation, commercial expansion, governance, and geography.

Regarding the colonial exploitation as a cause of the IR looting labor and natural resources from the world - the Marxist authors are in a peculiar position. For them, the IR was the inevitable result of the capitalist productive forces development, something specific to Europe. However, to arrive at the IR the development of the capitalist productive forces depended on an exogenous element: a "primitive capital accumulation" by looting the world's riches. For Pomeranz (2000) and Hobson (2004), the colonial exploitation was also a decisive, however a contingent factor. For others, the commercial expansion, not exploitation, regardless if backed by force or not, was a decisive factor explaining the IR as it provided economies of scale, which would be essential to, at least, start it (Deane and Cole, 1962). Hobsbawn (1977) stressed its importance to the British cotton industry, which started the IR. For Inikori (2002), more than an initial condition, the expansion of the international trade was the primary cause of the IR in England, as it stimulated technological innovation; the first "exportled" industrialization in history!

As for the governance - the role of the State in promoting industrialization it is worth note the work of Vries (2015). For him, this was the big difference between Britain and China, capable of explaining the great divergence. It was so decisive a factor that the relevant divide of the controversy should be reframed: in one side those, the institutionalists like Landes (1998), pointing out the lead of the private sector and, on the other side, those like him seeing the State as the leading promoter of the IR. Finally, the contingent geographic argument. For Morris (2010), geography was critical - location, location, location! - to the point of pushing forward Europe in a period when it was a backyard region as compared to Asia.

For "Eurocentrics" like North, Wallis, and Weingast (2009) and Acemoglu and Robinson (2012), the peculiar European features were primarily institutional. A new set of critical institutional innovations were consolidated in England in the 17th century, thus, creating the conditions for the emergence of an open access social order or inclusive political institutions, which were the necessary conditions for a process of sustained economic growth leading to the IR. McCloskey (2006, 2010 and 2016) criticizes this institutionalist view, arguing that in this perspective the institutions appear somewhat ad hoc as a fundamental explanatory factor, when in fact, they would be part of a process that starts with a decisive cultural change from 1700 on, brought about by the rise of the bourgeoisie and its values - bourgeois virtues, dignity, and equality. Mokyr $(1990,2010,2016)$ has the same perspective, though focusing on the cultural phenomenon represented by the emergence of a "culture of growth" in the 16th century. However, although Mokyr and McCloskey acknowledge for the medieval roots of these cultural phenomena, they downplay its legacy. The argument developed here is intended to show, on the contrary, the importance of this legacy. To show why the origins of the IR are in the peculiar traits of a new Civilization that emerged in the European Middle Ages. As the analyzes of medievalists like White (1962) and Gimpel (1975), among others, suggest, the 18th century IR was much more the result of an unprecedented evolutionary process that started in the Middle Ages when a "mutant Civilization" first 
emerged - an expression used by Braudel (1979) to characterize a Civilization that permanently changes itself by allowing the introduction of all sorts of innovations (technological, organizational, institutional and cultural). A situation in stark contrast to that of all other civilizations, in which an aversion to innovations prevailed as they were disruptive to established orders considered ideals. As Needham (1969, p.119) noted, Europe had something like an "intrinsic quality of instability" in sharp contrast to the Chinese "spontaneous homeostasis.

Acemoglu and Robinson (2012) are correct when they postulate that the history of nations' wealth and poverty is the history of overcoming the inherent resistance from political orders to the "creative destruction" process by the systematic introduction of innovations. Economic growth is "subversive" because its continuity depends on the continuous introduction of innovations that affect all society's spheres of activity, creating winners and losers. For this reason, the process of introduction of innovations the political orders need to constitute as such tend to cease as they consolidate. The vested interests behind consolidated political orders begin to react against the introduction of innovations viewed as threats; even the general population that supports these orders through painful labor also come to consider them as permanent 'natural' orders, the custodians of honorable traditions (religious, cultural, social).

In medieval Europe a different, unprecedented, situation occurred. The medieval political orders had this "intrinsic quality of instability" due to peculiar cultural and political characteristics that interacted to prevent the blocking of the introduction of innovations. A culture that also favored the work of manipulating nature in search for better material comfort within a general competitive order: the competition between feudal orders and, within them, the existence of self regulated institutions and organizations independent from the State that exerted a counterpower. That was an exceptional situation that offered an unparalleled degree of freedom to innovate.

In short, the comparative historical analysis shows that, in Western Europe, peculiar cultural and political features combined to drive a new civilizational path since the fall of the Roman Empire that was different from those followed by all civilizations. The Industrial Revolution did not occur there by chance but was the result of an evolutionary process driven by the introduction of innovations beginning at the High Middle Ages. Capitalism, Industrial Revolution, and Modernity were path pendent European phenomena which, for the first time in the history of human civilization, shattered the "glass ceiling" that had blocked a sustained economic growth in all civilizations that could have led to an Industrial Revolution.

The article starts with an analysis of cultural factors (2) in two subsections, one (2.1) on the worldview of the period and another (2.2) on the emergence of individualism. Then, it follows an analysis of the political/institutional factors (3). The following section (4) is dedicated to the analysis of the actors of the evolutionary political/institutional/cultural processes and has been subdivided into five subsections: (4.1) the peculiarity of feudal states in Europe; (4.2) the role of an independent religious organization; (4.3) the autonomy of the universities; (4.4) the entrepreneurship of the monastic orders; (4.5) the independence of the cities. The objective of the fifth section (5) is to show the economic consequences of such political/cultural dynamics. The sixth section (6) comprises the final considerations. 


\section{The cultural factors}

\section{A peculiar worldview}

Although originating in the Middle East, the Judeo-Christian worldview blossomed in Latin Europe in all its potential as an essential cultural factor to explain the extraordinary innovation dynamics observed since the beginnings of what eventually became the Western Civilization. In this worldview, the human being is seen as the center of divine creation and has nature at its service. For White (1967), this fact led to a desacralization of nature, in which God and the Saints substituted nature as the divine/spiritual locus, thus, providing much greater freedom to its manipulation. Furthermore, manipulating nature is the very essence of innovative technical progress, as noted by Mokyr (1990). Another characteristic of this worldview is a linear concept of time, usually progressive towards a better world, although it could be regressive. This concept is in sharp contrast to the cyclical conceptions prevalent in other civilizations, where the idea of progress was lacking. Finally, the respect for labor found in the Old and New Testaments, which, beginning in medieval Latin Christianity monasteries, translated into a much respected social value, in sharp contrast too to the prevailing view of labor as something degrading.

For Le Goff (1990), the social attitudes developed during this period of the Western civilizational process were decisive for its future. Regarding labor, starting from a tradition of contempt (including to the work of engineers) inherited from the Greco-Roman world and from a pessimistic idea of working as a curse, punishment, and penance, it evolved by multiple paths to an attitude of appreciation with a proper concept and vocabulary for labor and laborers. The monasteries played a crucial role in this process, in the solution of a socioideological conflict regarding labor stemming from The Rule of Saint Benedict, "ora et labora." Working is a penance, yes, but a blessed penance

The conflict between the two great monastic orders of the period, Cluny and Citeaux, had as one of its motivations precisely the relative weight that should be attributed to each of these Benedictine injunctions. In the end, Citeaux's idea of labor prevailed, as something that dignifies the human person, worthy of heavenly blessings as represented by the patron saints of the corporations. These corporations, as will be seen later, were decisive organizational innovations for medieval commercial and preindustrial revolutions. Oxele (1990) also points that the consolidation of the mental schema associating three ranking orders with three social functions in the 11th century, in which the social function of labor was placed alongside the social functions of prayer and military protection (oratores, bellatores et laboratores), reveals a remarkable appreciation of work. The "laboratores" began to appear far more actively in historical settings through social organizations of peasants, artisans, and merchants, which grouped themselves into sworn associations in public oaths for mutual assistance and protection. 


\section{Individualism versus familism}

Another fundamental cultural factor was the medieval European exceptionalism regarding the end of tribalism. State effectiveness depends on the displacement, to some degree, of an individual's loyalty from family/kin group to State. However, in all civilizations, institutions based on territory and centralized legal authority had to be superimposed on societies where the familism from tribal origins remained as the primary organizational force of society's members societies based on agnatic lines (patrilineal) (Fukuyama, F.2011). In the European case, the networks of familial relations as the basis of the political relations disappeared with the emergence of feudalism, as a result of two forces acting simultaneously. The first was the sociocultural influence of a religious institution that, since the end of the Roman Empire, had been spreading a new pattern of marriage in Western Europe. As Goody (1983) showed, the Mediterranean pattern was strongly patrilineal, resulting in a society segmented into endogenous groups with rigidly defined boundaries, and with a particular preference for marriage between cousins. There was a strict separation of the sexes and very few opportunities for women to own property or take part in the public sphere.

In the new pattern of marriage promoted by the Catholic Church, inheritance became bilateral (by man and woman), intermarriage banned, and exogamy stimulated. The Church also banned other familial strategies to maintain the property within the family group, such as widows' marriage within the family, the divorce of women by men, concubinage, and adoption of children in the absence of a male heir. Women came to have greater property rights and participation in public life. The role of women in converting pagan kings is noteworthy, being crucial for the expansion of Christianity in Europe - beginning with the conversion of Clovis, king of the Franks in the 8th century, under the decisive influence of his wife, Clotilde. Pernoud (1980) pointed out the significant number of similar cases to show it was not a coincidence but the result of the strong attraction Christianity exerted on women by proclaiming and promoting equal rights between men and women; as a result, women became active evangelical preachers. By the end of the 4th century, thanks to the influence of the Catholic Church, the Roman civil law had already been modified, especially the removal of the father's right to the life and death of his children. This change was particularly beneficial to daughters who tended to be sacrificed if there was already a female firstborn.

It is worth notice that the empowerment of women in the new type of marriage promoted by the Catholic Church was not in disagreement with the status of women in the Germanic tribes that invaded the Roman Empire, judging by the evidence available from certain peculiar characteristics of these tribal societies. Among these characteristics, Jones (1987, pp.14-15) points the persistent tendency to keep population growth below what would be its maximum to maintain land available for pasture and forests, resulting in consumption patterns (especially of meat) different from those prevailing in Asia. Individuals in these tribal societies were willing to exchange children for goods at the margin to maintain a given standard of consumption, which "empowered" women. Based on Hajnal's (1965) study, Jones notes the prevalence of later marriages and a high percentage of unmarried individuals as a distinctive European element - women had the right not to marry. Individuals were encouraged to accumulate goods before marriage and constituted nuclear families 
relatively independent from larger familial circles. Moreover, this behavioral pattern could go back to the 2 nd millennium BC.

Therefore, European society was individualistic from an early age in the sense that it was the individuals rather than their extended families (clans) who made important decisions about marriage, property, and other personal matters. As a result, State institutions were superimposed on societies in which individuals already enjoyed considerable freedom from familistic obligations. For this reason, Fukuyama (2011, p.231) considers it appropriate to claim that "the social development in Europe preceded the political development".

The second force destroying familistic relationships as the basis of social organization was the European peculiar feudal vassalage system. For Bloch (1949), feudalism was formed "in the fiery furnace" of invasions and immense disorders, being a desperate self-defense response there off, that demanded new forms of articulation between isolated groups that were not related by familisticties. In other words, feudalism emerged as a non-familistic alternative of social organization. Familistic structures no longer provided adequate protection, to the extent that they were already actively undermined by the exogamous marriage rules defined by the Catholic Church. Thus, the essence of feudalism was the voluntary submission of one individual to another, not based on kin relationships, but on exchanging of protection for loyalty.

Thus, as Fukuyama noted (2011), during the medieval period, before the formation of the centralized National States and centuries before the Reformation, the Enlightenment, and the Industrial Revolution, Western European societies had already become much more individualistic than any other society that ever existed. Therefore, a transformation that did not result from these significant modernizing changes, but on the contrary, it was an essential element explaining their emergence. As a result, the emerging capitalist economy had not to face the resistance of large, corporately organized familistic groups with substantial property to protect, as it happened in China or India, but instead, it advanced in societies where property routinely changed hands between strangers (non-relatives).

\section{The political/institutional factors}

Another decisive element in explaining the European specificity was the fragmentation of power, a necessary condition to avoid the formation of despotic regimes. The fragmentation was due to geopolitical factors (regions and states in competition), as well as to the emergence of State independent institutions and organizations. Thus, the very emergence of centralized States in Western Europe occurred after or concomitantly with the emergence of the conditions for a less authoritarian political order that became progressively more democratic.

As defined by Fukuyama (2011), a fully democratic political order occurs when the State is effective, but subject to the Rule of Law (a Constitution and an independent judiciary), creating Accountable Governments (in the face of parliaments, assemblies and other political bodies that represent broader sectors of the population). Although a despotic State may be effective, it is unpredictable due to personal inclinations, caprices, of the successive despots. Alternatively, as in the case of the precocious and highly despotic Chinese State, which was quite predictable in its aversion to changes in the status quo. There is no minimum 
security and freedom necessary for individuals and innovative initiatives to thrive.

Similarly, for North, Wallis, and Weingast (2009), the social order most compatible with the blossoming of individuals and initiatives is the Social Order of Open Access. Open access to the economic and political systems. Open access to the economic system serves to prevent the manipulation of economic interests by the political system. In turn, the open political system allows the group in power to be contested through prescribed constitutional means. All citizens have the right, defined impersonally (equality is impossible without impersonality), to form organizations without the consent of the State, which ensures non-violent competition in politics, economy, and in virtually any area of open access society. Along the same lines, Acemoglu and Robinson (2012) consider the emergence of inclusive political institutions, which replaced previous extractive political institutions, as the fundamental cause of the great divergence in development between Europe and the rest of the world. For them, however, the relevant period of analysis starts at the end of the 17th century, with the Glorious Revolution in England. Until that moment, the existing social orders were closed, and extractive political institutions prevailed.

On the contrary, this paper is arguing that the constituent elements of a democratic political/social order evolved exceptionally and precociously well before the 17th century, leading to the formation of relatively open access polities, with a predominance of individualism in the social sphere and of Stateindependent organizations and institutions. This exceptional evolution explains European technological, organizational, institutional, and cultural creativity. Capitalism, the Industrial Revolution, and Democratic Modernity were not developed in Europe by chance. They are the result of a unique evolutionary process. This process started at the beginning of feudalism, between the 5 th and 10 th centuries. Its apogee, between the 11th and 13th centuries, was driven by a sequence of institutional, organizational, and macro and micro technological innovations, which deeply transformed its nature, giving birth to capitalism and causing commercial, preindustrial and agricultural revolutions. The main actors that ensured these dynamics were feudal States, cities, the Church, monasteries, universities, and corporations.

The feudal States consolidated at the end of the 10th century competed and with the cities. Their leaders were kings who were also feudal lords, being only "primus inter pares." They were the suzerains of several manors, having vassals who, as a rule, had vassalage relationships with other lords simultaneously. Eventually, the vassals acquired full control of the land, which was passed on directly to the heirs. Therefore, the power of the feudal aristocracy limited the royal power, and differentiates itself into high and small (gentry) nobility, acting through representative assemblies.

On the other hand, the cities had an independent and innovative form of governance, the Commune. Alternating alliances with monarchies and feudal aristocracies, arming themselves, and being able to defeat even the Emperor, the cities played a decisive role in the medieval political order, which was unique in the history of civilizations. They came to form an internal frontier to the landed feudal estates that increased a lot the mobility of labor. Such greater mobility exerted a permanent evolutionary impact on the relations between masters and servants. From an economic point of economic view, the cities caused a decisive impact by engaging in international trade very early, creating a large market space that united Northern Europe (Baltic Sea) and Southern Europe (Mediterranean Sea) and Europe and Asia/North Africa. 
The Catholic Church, as an independent religious institution, was able to define a field of spiritual power prerogatives separated from temporal power, as well as to play a decisive role in defining and legitimizing a superior law under which everyone, including the monarch, was subjected. Linked to this institution, but having considerable autonomy, were monasteries and universities. Monasteries, although capable of acting directly in the political game of power, had their most notable role as innovation centers of all kinds, agricultural and industrial, acting as "proto-capitalist" enterprises. Universities were autonomous centers of thought and acted corporately; on the one hand, they had an unparalleled evolutionary impact in the political and philosophical debate; on the other hand, they had an impact on the legal order by training an entire category of legal experts who were at the origin of an independent and professional judiciary, a necessary condition to consolidate the "Rule of Law."

Finally, the craftsmen corporations, the Guilds. These professionals' associations also performed a significant role in the political game, especially within the governance of cities in alliance with the Communes. They also played a decisive role in the development of industrial and commercial activities. The Guilds dignified labor, reflecting a change in the old mentality about its value, which used to be non-honorable in all civilizations.

\section{The peculiarity of the feudal states in Europe}

As shown above, the formation of the feudal states in Europe resulted from the effort to build a defensive system in the absence of tribal/familistic relationships - the vassalage system. Another key characteristic of feudal states was that its legitimacy heavily depended on the capacity of feudal kings to provide justice. They were nothing more than "primus inter pares" within a decentralized feudal order. They spent most of their time traveling through their realms, as this was the only way to assert their authority and maintain communication in a fragmented world of isolated villages and fiefdoms. One of the primary services the king could offer was to serve as a court of appeals to individuals who were dissatisfied with the rulings of the local ruler. Of course, it was in the kings' interests to expand the jurisdiction of their courts. It increased their authority and prestige, besides being paid services. Itinerant royal courts had the advantage of being more impartial due to having fewer bonds with litigants than the local lords. They also presented procedural advantages, such as the ability to compel citizens to serve as jurors and, over time, they began to enjoy economies of scale and scope. The administration of justice requires specialized work performed by better trained personnel.

It is important to note that it was not a simple matter of administrating justice, something that was the responsibility of the rulers of any civilization but administrating it under the "Rule of Law." The Law consists of a body of abstract rules responsible for the cohesion of a given community. In premodern societies, the Law was supposed to originate from an authority superior to any human legislator, whether it was divine authority, an immemorial custom, or nature. The Legislation, in turn, corresponds to what is now called a positive law, being the responsibility of the political power, i.e., the responsibility of the king, warlord, president or legislature to elaborate and enforce new rules based on a combination of power and authority. The "Rule of Law" only exists when a preexisting body of laws (based on a religious text or a constitution as in the Modern States) is sovereign regarding the legislation, thus limiting the rulers' 
power. Law and Legislation currently correspond to the distinction between constitutional laws and ordinary laws. Therefore, the prevalence of the Rule of Law implies a limitation to the power of the State.

However, the conditions for the proper functioning of the Rule of Law go beyond institutional or procedural aspects: the Law must be perceived as fair, and no exceptions in its application can exist. The kings and the seigneurial barons could not be above the law, which, ultimately, had its value derived from a religious sanction. Therefore, in its more profound sense, the Rule of Law means that there is society's consensus that its laws are fair, and that they must preexist and regulate the behavior of whoever is the ruler at any moment. The Law is sovereign and not the ruler. The legitimacy of the ruler depends on the Law. In the past, the primary source of fair laws outside the political order sphere was religion. However, for these laws to be respected by the rulers, the religious authority had to be asserted independently from the political authority, as was the case with the Catholic church.

\section{The role of an independent religious organization}

As Fukuyama (2011) showed, religion did not reflect a sociocultural consensus in China but usually served as a source of social protest. The Chinese State has never recognized any religious source of authority as superior to its own and has always easily controlled every religious class that ever existed. Therefore, there has never been a Rule of Law based on religious authority in China. In its legalistic tradition, all the laws were considered positive laws, i.e., the Law was whatever the Emperor decreed.

In India, the situation was completely different. Brahmanism, which developed concurrently to the formation of the Indian states, was able to subordinate the political/warrior class to the priestly class. The Law had strong roots in religion, and there was no separate secular lawmaking field. However, the priestly class (Brahmin) as not organized within a church in a hierarchical way as in the West. This class acted in a fragmented way, divided into different for subclasses defined by the functions performed (those conducting the rites of the investiture of kings, those conducting funerals, and the likes. They never subordinated themselves to the State, nor became officials, but were incapable of collective action through an institutional hierarchy. In the domain of Islamic Civilization, there was a Rule of Law based on religious authority, but not a religious institution independent of the State. There was a greater law of divine origin clearly expressed in the Qur'an, which gave origin to a codified body of laws - the Shariah. The legitimacy of the temporal power was conditional for the application of Islamic law. As a result, religious and secular powers fused into theocratic political orders.

In Western Europe, the Rule of Law was institutionalized to a much greater extent. In addition to the specificities of feudal states, the fundamental explanatory factor for this difference was the presence of a religious institution that achieved a degree of autonomy and influence unparalleled by the religious institutions in other civilizations. After the fall of the Roman Empire and the subsequent weakening of political power, the Catholic Church was able to assert its independence. However, such independence started to erode as feudal political orders began consolidating; the appointment of bishops and even popes became a common prerogative of local and regional political powers, as well as of the 
Emperor himself. However, by the end of the 11th century, the Church was able to, once again, incisively assert its independence from secular powers.

For Fukuyama (2011), this ability undoubtedly depended on the energy, tenacity, and determination of a man like Hildebrand, a monk who became Pope in 1073 under the name of Gregory VII. He was determined to end the corruption and rent seeking that this system of appointments promoted, reinforced by the fact that priests could marry and bequeath to their children properties that should belong to the Church. Compulsory celibacy solved this last problem. To solve the first one, he directly attacked the right of secular powers to appoint bishops and priests, making it an exclusive prerogative to the Church itself. Moreover, he advocated the legal supremacy of the popes over all Christians, including the Emperor (who could be deposed).

Emperor Henry IV's reaction was to attempt deposing the Pope, who retaliated by excommunicating him. The excommunication made the Emperor undergo a barefoot walk during the winter of 1077, in a historical episode, to humbly ask Gregory VII for his forgiveness while he was waiting for him in the fortress of Canossa (north of Italy). However, this conflict over the "right of investiture" will only end in 1122, after many back and forth arguments (Gregory VII died in exile in 1085) with the Concordat of Worms, through which the emperor Henry V, son of Henry IV, recognized the Church's right over the investiture (appointments); the Church, in turn, recognized the Emperor's right over several temporal matters. The Church's ability to sustain the independence policy started by Gregory VII and to stand as an autonomous political power depended certainly on the peculiar political fragmentation of Western Europe. It allowed the Church to seek protection by playing with different rivals. The kings of the Norman kingdom in Sicily played a decisive role in supporting the Church against Henry IV and his son Henry V, emperors of the Holy Roman Empire.

For Fukuyama (2011), the investiture contest, in addition to contributing to consolidating the Church as an institution with autonomous political power, as well as an organization of high complexity and capacity for adaptation, had, as a consequence a clear cut separation between the realms of temporal and spiritual powers, laying the foundations for the emergence and consolidation of the secular State. Finally, this conflict was essential for the development of both the Law and the Rule of Law in Europe. For the development of the Law to the extent that this conflict stimulated the Church's efforts to gain legitimacy through the formulation of a regular legal canon, the Canon Law and for the development of the Rule of Law, as the Church was able to create a separate and well institutionalized domain of spiritual authority with universal jurisdiction.

\section{The universities}

Searching for sources of law that would serve to strengthen the claim of universal jurisdiction in some issues, Gregory VII's successors rediscovered the Codex Justinianus (Justinian's Code) at the end of the 11th century. From this moment on, this Code became and remained until today, the basis of civil laws practiced throughout continental Europe and in countries that were colonized or influenced by it. The strength of this revival of Roman law mostly resulted from the establishment of Law studies programs on new institutional bases with the "invention" of the University. The origins of universities are in the schools of the Cathedrals, beginning in Bologna in 1088. The fundamental difference between the University and the other types of higher education institutions in Europe and 
other societies lied in the freedom and autonomy for research and debate. All levels of power granted such freedom and autonomy. In 1158, Emperor Frederick I (also known as Barbarossa) promulgated an "Authentica Habita" (a university's organic law) that transformed the University of Bologna into a "city-state." The municipalities competed for having the privilege to host a University. The papacy defended the universities' autonomy over the established powers and respected their research agendas, even when they contradicted the Church's doctrines or guidelines.

Discussing the fact that universities openly flouted the Church's restrictions on the dissection of corpses, Schachner (1938, p.3) noted that:

"The university was the darling, the spoiled child of the Papacy and the Empire, of king and municipality alike. Privileges were showered on the proud Universities in a continuous golden stream; privileges that had no counterpart, then, before, or since. Not even the sacred hierarchies of the Church had quite the exemptions of the poorest begging scholar who could claim protection of a University. Municipalities competed violently for the honor of housing one within their walls; kings wrote siren letters to entice discontented groups of scholars from the domains of their rivals; Popes intervened with menacing language to compel royalty to respect the inviolability of this beloved institution."

The new Law curriculum at the University of Bologna attracted students from all over Europe. Soon, the other universities began to compete strongly in this field, notably the University of Paris. Thus, the sophisticated legal system of Justinian's Code became the model for the legal systems in several regions. After an initial period of reconstruction and reproduction of Roman law, generations of "scholars" went further in the search for the intellectual foundations of Law, reaching the Greek philosophers. Classical philosophers e Aristotle thought that the legal tradition received had to be submitted to human reason and confronted with more universal standards of truth. In this sense, the rediscovery of the classical philosophical tradition in European universities, especially by the work of Saint Thomas Aquinas at the University of Paris, encouraged successive generations of legal commentators to go further than the mechanical reproduction of an existing body of laws, rationally reflecting on the sources of law and how they could be applied in new situations.

A separate class of legal experts emerged from universities; they acted similarly to the members of a guild in perfecting their "art." Over time, both religious and lay authorities understood that they had to rely on the knowledge of legal experts when making decisions, especially in the commercial sphere where contracts and property rights were critical.

Starting from the Gregorian reform, the Church gradually acquires a State structure, having its legislation - the Canon Law - and a professional bureaucracy like the Chinese's developed centuries before. The Gregorian reform offered not only a bureaucratic and legal model for the new centralized States that were starting to emerge in Europe but also stimulated the emergence of several new legal forms related to different domains - the fiefdom, the city, longdistance trade -, which motivated the competition between jurisdictions. The rise of the independent cities was particularly crucial for the development of commercial law due to their dependence on foreign trade. Therefore, as noted by Fukuyama (2011), the Rule of Law existed before the political power was concentrated in the hands of centralized governments. 


\section{The monastic orders}

Monasteries had a pioneering role in the systematic search for innovations of all kinds, especially the monastic order of Citeaux. As seen, this order won the "socio-ideological" battle in favor of the idea that work is dignifying to man. The new monastic orders became "farming models." They also transformed many of their monasteries into models for solving non-agricultural technical problems, from reinforcing and maintaining dikes in the Netherlands to well drilling and bridges construction techniques and various industrial activities that eventually became specialties of each monastery. The monasteries evolved to become proto capitalist enterprises, where the work was valued, but not heavy and repetitive. Creative work was the most valued, including that of the engineers who invented ways to make it less painful.

A document from the 13th century on the role of hydraulic energy in the mechanization of work in the Cistercian monastery of Clairvaux gives a remarkably clear idea of the level of mechanization attained and the enthusiasm for its adoption:

"A branch of the river, crossing the numerous workshops of the Abbey, makes itself felt everywhere by the services it provides [...] the river is first launched with impetuosity on the mill, where it becomes very agitated and writhes, both to grind the grain under the weight of grinding stones, as well as to stir the sieve separating the flour from the straw. Then, it goes to the next compartment; it fills the boiler and surrenders itself to the fire that cooks it to prepare the beer of the monks if the harvest of grapes was not good. The river does not give up. The cloth pressing mills call it in turn. The river that was busy preparing the monks' food, now thinks about their vestments. It does not refuse anything that it is asked for. It raises or lowers these heavy pestles and hammers, or rather, these wooden feet, thus sparing the monks from great fatigues [...] how many horses would be exhausted, how many men would fatigue their arms in this work made for us by this graceful river, to which we owe our garments and our food. When it spins so many fast wheels, it comes out foaming as it were ground. When it leaves, it enters the tannery, where it prepares the leather necessary for the monks' shoes; it shows both activity and care, for it divides himself into numerous small arms to visit different services, diligently searching everywhere for those in need of its services, whether it was to cook, tan, break, wet, wash or grind, never refusing to offer its services. Finally, to complete its work, it takes the filth away, leaving everything clean".

\section{The independent cities}

The distinctively unique character of the medieval towns in Western Europe resulted from a process that began with the Italian port cities on the Adriatic coast and was extended inland under their leadership. According to Lopez (1976), these cities, as was common to all cities, kept vassalage links with more than one lord to remain relatively independent. However, the difference is that these port cities, notably Venice and Amalfi, had connections with the Byzantine Empire, which may explain the fact that their elites - including those that were landowners -actively took part in maritime trade from an early stage. Venice was politically independent but had the Byzantine Emperor as the city's lord, providing him naval support, as well as intermediating the exchanges with the 
Western Empire (Carolingian). Venice also maintained commercial relations with the Islamic world in the Middle East and North Africa. A thriving commercial triangle: Eastern luxury goods (mainly spices, silk, and jewels) and Western commodities (iron, wood, naval supplies, and slaves), as well as "Venetian" goods (salt from their lagoons and glass). The position of Amalfi was similar, changing only the types of goods produced locally: great quantities of locally produced textiles and olive oil. However, it was not as politically independent as Venice due to not having the protection of the sea against the surrounding feudal lords.

As the progress of Venice and Amalfi was shifting the center of naval and economic power to the Italian peninsula, two ports on the other side joined them, Genoa and Pisa. Conjointly, these cities managed to expel the Muslims from Corsica and Sardinia, putting an end to the looting and devastation they used to cause. In these cities, virtually all the inhabitants were free men and participated in some way in municipal assemblies and minor administrative activities. The merchants of these cities served in the army together with landlords having similar incomes; with all the citizens, they were responsible for the defense of the city walls.

The younger sons of the surrounding feudal nobility found in the Italian cities an economic opportunity in commerce, as well as the opportunity to perform the activity they trained for their entire lives: the military combat, frequently facing pirates, "infidels", competing cities and in the "opening" of markets. Merchants and the nobility merged, including literally through marriage: from the 12th century onwards, they became part of the category known as "magnates", who distinguished themselves from the rest of the population by their level of income and not by titles of nobility. For this reason, it was comparatively easier for the urban population to depose or buy the city's feudal lord and establish their communal government under the magnate's leadership, but with the participation of all citizens in varying degrees.

Inland cities had much more difficult to conquer their independence from the feudal lords, whose heavy cavalry was initially superior to the forces of the bourgeoisie, composed by spearmen phalanxes supported by crossbowmen. Over time, the accumulation of military capacity allowed them to force local lords to become members of the Communes as the only alternative to total ruin. In 1176, the Lombard League defeated in Legnano the supreme lord of Italy, the Emperor Frederick Barbarossa, thereby conquering complete independence; after the defeat, their vassalage bond with the Emperor became just nominal. Shortly after, the cities of Tuscany reached the same status without having to fight. In the 12th century, the Italian communes had essentially become "merchant governments, by merchants and for merchants" (Lopez, RS 1976).

As noted by Lopez (1976), the urban commercial revolution in medieval Europe allowed, in an unprecedented way in the history of civilizations, the liberation of the agricultural surplus for investments in the business, as well as allowing more flexible credit operations. The substantial expansion of credit was the great lubricant of this revolution in the context of inflation and shortage of currencies. This expansion was achieved through new partnership formulas and other arrangements for sharing risks and profits. Innovations which resulted, according to Lopez (1976, post.951), from the Church's insistence that loans were sinful unless they were granted without interest and in the spirit of charity, following the same attitude of cooperation that involved the men of all classes in the political struggle that eventually led to the rise of the independent Communes. Commercial contract development was as crucial in the history of trade as that of tools and techniques in the history of agriculture. 
Banking and financial development were practically a byproduct of the expansion of international trade. What local deposit bankers could not do - as they had a limited amount of capital, were regulated by municipalities, and were liable to be sued by ecclesiastical courts for usury - was far easier for merchants engaged in international trade. Foreign operations and the contractual innovations introduced by it, allowed them to legally engage in the same credit operations in connection with their commercial activities. In essence, they accepted interest bearing deposits, subsequently extending larger interest loans without the risk of being condemned by the Church. They fully benefited from innovative instruments such as the bills of exchange to charge the interest rates they wanted. These bills consisted of contracts in which one party received an advance in local currency from another and promised to pay it back in another currency elsewhere. The primary purpose of this type of contract was to provide the second part of the money needed overseas, saving it from the risk and cost of traveling with local money. This scheme entitled the first party to charge for funds transference and currency exchange services. Given that a certain period elapsed between the advance in local currency and payment in foreign currency, the transaction involved a loan from the second part to the first, whereby the first part paid an interest hidden in the exchange rate.

The Commenda was another contractual innovation of extreme importance; it was the closest medieval antecedent to the concept of the modern corporation and, like many others, involved some form of credit. In its simplest form, a merchant from one city advances capital to another who is willing to travel to conduct business, the former takes the risks of capital and is entitled to $3 / 4$ of the profits; the last assumes the risks of the work, being the only one responsible for the commercial transactions performed and gets $1 / 4$ of the profits. The same merchant who lends money to another also does the reverse, receiving capital from other traders to invest in business expeditions. In the beginning, in the first contracts, accountability was demanded to be supported with some proof for the profits obtained; however, over time, the businesses were made from mutual trust. Eventually, commercial activities become routine, and competition reduced the profit rate. More experienced traders could run their business through employees and commercial agents, without having to travel. By the beginning of the 14th century in Italy, the average interest rate on commercial loans had fallen to $8-12 \%$. In Germany, the legal rate was still $43 \%$ (in Nuremberg).

During the 13th century, the gravity center of the Mediterranean definitively moved to the "big four" of Central and Northern Italy: Venice, Milan, Florence and Genova. Only the Catalan traders were able to compete with the Italians, and at the beginning of the 14th century in the rest of the Mediterranean basin, they controlled an essential part of the long-distance international trade. In the North, the end of the invasions and the expansion agricultural from the 10th century on, allowed several German cities to develop their own local and longdistance commerce (in the Baltic) and, as in Italy, also allowed them to challenge the emperor's and his vassals' authority to build their own commercial and colonial empire eventually. The main products traded in the Northern Mediterranean were fiber, grains, wood, resins, tar, honey, wax, skins, precious and semiprecious metals, wool, salt, and salted herring. In the Western corner of the Baltic sea, the British and Dutch managed to control the trade, but many commodities of the Atlantic regions, such as Gascon wine and Basque iron, were traded by local merchants; everyone performed short-haul cabotage. Local merchants took virtually all the production from inland regions that were far from the sea to the main centers, where the Italian merchants predominated. 
The fairs of Champagne eclipsed all others from the end of the 12th century until the beginning of the 14 th century. These fairs successfully innovated by operating in rotation between the cities of the region throughout the year. They worked mainly as centers to exchange money and goods for merchants who converged there from all over Europe and were not interested in local businesses. The goods were presented as samples at most, and credit instruments almost entirely replaced the currency. The fairs declined when the Italians began to go directly to the ports of the North Sea with their ships, establishing permanent offices there.

In the North-South-Orient (the Levant) commercial axis, through Italy, the goods from the South came in two groups of high-value products: raw materials, like spices (spices, especially pepper which was also a food preservative) and medicinal products, fabric paints, raw silk, precious stones, and ivory; from the North, initially came non-precious metals and wood, followed by a growing and varied list of industrial products (glass, weapons and other iron goods and, above all, linen and wool fabrics).

Lopez (1976, p.107) considers that "perhaps the most striking byproduct of commercial trade's growing maturity was the consolidation of colonies and the increasing reliance of international traders on quasi-sedentary agents abroad." That was not a byproduct, but a decisive factor pushing the commercial expansion. The reliability of such a scheme, in turn, was the result of two organizational/institutional innovations: The Commune and the community responsibility system. These two innovations generated peculiar State governance in the absence of centralized territorial states, being relatively democratic, capable of protecting the property rights, as well as of providing two essential conditions for the expansion of the merchants' commercial activities: the possibility of hiring agents abroad without being deceived (the principal agent problem) and the protection against predatory rulers of foreign jurisdictions.

The Commune was a temporary voluntary sworn association, led by consuls elected for a limited period by a parliament composed of all citizens with "full rights." Such organizations were a self-governing community that occupied a gray area between the State and the communities. A Commune was like a community insofar as characterized by intra-community personal familiarity, but also as a State as it had a geographically localized monopoly of the legal use of coercive power.

The community responsibility system involved the association between municipalities and trade Guilds. This system managed to coordinate the collective action of a group of interests, such as the merchants of a city, preventing the group's internal conflicts and, at the same time, allowing the establishment of long-distance commercial activities between economic agents unrelated by kinship and with property rights secured vis-à-vis potentially predatory states. In the community responsibility system, the court of a Commune held all members of another Commune accountable for the damage caused to one of its members. If the deceiver's Commune refused to compensate the deceived agent, the Commune court of the deceived individual would order the confiscation of the property of all the members of the deceiver's Commune to compensate the deceived agent. The only way for the deceiver's Commune to avoid compensation would be to have no business whatsoever with the Commune of the deceived agent. However, this could be very costly. Therefore, the most sensible behavior of the court of a Commune was to dispense impartial justice by punishing its fraudulent member. This system transformed Communes into 
perpetual life organizations, which internalized the cost of a fraud performed by any of its members against members of another community (see Greif, A.2006).

Therefore, the binomial Guild-Commune solved the problem of impersonal exchanges in premodern Europe, which are characterized by the separation of quid and quo through jurisdictional boundaries, through a self-enforcing institution. A private order based on institutions capable of enforcing the rules they created was the hallmark of the medieval trade expansion. An order resulting from the coordinated efforts of many individuals unrelated by kinship bonds. The social structures created through these efforts were self-governed and based on the mutual interests of their participants. They were self-governed as their members participated in the creation of the rules to govern their activities, which legitimated them. In this sense, Greif (2006) considers that the traditional understanding that the emergence of centralized states was a precondition for the expansion of markets should be reviewed in the light of the history of the community responsibility system.

\section{Capital accumulation and labor productivity}

The Commercial Revolution, promoted by the independent cities, caused a substantial impact on the agricultural and manufacturing sectors, which were already evolving through the introduction of several innovations.

\section{A preindustrial revolution}

The significant enlargement of the commercial space that was made possible by the community responsibility system, commercially uniting the whole European area, in addition to the international trade with the East and North Africa, significantly increased the productivity system by allowing regional specializations. The productive process itself underwent continuous changes, which increased labor productivity. Initially, the Guilds, corporate craft organizations (an important institutional innovation) played a central role in the organization of the labor process and the improvement of production methods. Their origin lied, like that of their commercial counterparts, in the mutual aid confraternities with their respective patron saints, which characterized the evolving social life in the cities. The work in Craft Corporations was hierarchically structured, from the apprentices to the master, but mobility existed through talent and dedication. The corporation established the product quality levels and the fair price to ensure the adequate remuneration of the entire hierarchy of artisans. Under this form of organization, the craftsmanship quality of the works reached very high levels, as can be witnessed in the Dijon's Musée de l'Outil, with its vast collection of specialized tools of all kinds for the most perfected finishes.

The expansion of markets brought by the Commercial Revolution eventually led to the end of the craft corporations. From the outside through the "putting out" system: the innovators took the craft production to rural villages, far from the Guilds' jurisdiction. From within each workshop, as the superior productivity made possible by the fragmentation of the artisanal work into specialized operations of the working process began to impose itself in more dynamic sectors 
like the textile: the production of one piece of cloth went through 26 different operations, each performed by a skilled worker (Gimpel, J.1975).

For Lopez (1976), while the cotton based textile industry first started the Industrial Revolution in the 18th century, the wool based textile industry began the medieval Pre-Industrial Revolution in the 12th century. The first reason for that: the production process of textiles was initially divided into specialized operations run by different Guilds but eventually integrated into a single management unit. Each operation could be accelerated by relatively simple innovations - the pedal weaver replacing manual weavers and spinning wheels replacing hand spindles. The second reason was that the characteristics of both raw materials and finished products regarding the transportation costs allowed for a concentration of production in the most desirable places in terms of the availability of labor and entrepreneurial capacity, as was the case of the Netherlands in particular. The silk industry in Italy was not far behind the wool industry in the Netherlands. Furthermore, the production of linen fabrics had equal importance, especially for lingerie, with Switzerland and German Rhine valley becoming the main producing centers. Fustian (piquet), a new and cheaper textile product, was developed from a mixture of cotton and wool. Around 1200, a piece of piquet cost a twentieth of a piece of good quality wool. In short, Medieval textile output based on putting out system came close to the English textile industry on the eve of the Industrial Revolution.

\section{Agricultural expansion and labor productivity}

The dynamics of innovation in the agricultural sector caused a decisive evolutionary impact on a mostly rural society. Feudal rurality was shaped by the long centuries of disturbance and violence of the High Middle Ages ever since the fall of the Roman Empire. Regarding agricultural systems, the violence led to the abandonment of shifting agriculture: the populations settled around a warrior lord for protection. The ecological conditions for permanent agriculture are radically different from those for shifting agriculture (slash-and-burn). In a forest environment, shifting agriculture mainly consists of preparing the field of culture by burning part of the forest. The fire cleans the land, eliminating many harmful parasites and microorganisms, and fertilizing the soil through the ashes that contain the mineral elements left over after the burning of the forest's organic matter. Then, the soil is cultivated during a few years.

Once exhausted, it must be abandoned for a period long enough for the forest to recover. This period of forest recovery varied depending on the climate; in the tropics, it occurs faster than in the Northern regions. In Northern Europe, this period seems to have varied between 30 and 35 years. If the necessary recovery period is respected, this cropping system is perfectly balanced from the ecological point of view and can go on for centuries without degrading the soil or the forest. In this cultivation system, labor productivity is relatively high, being undoubtedly superior to the one obtained from the system of permanent culture that replaced it. This difference is mainly due to lower labor costs of soil preparation and weed control.

The structural conditions of a soil recently covered by the forest allow it to be sown immediately after burning it, a method that is currently known as no-tillage or minimum tillage, sparing the preparation labor. Further, weeds do not invade forest clearings. Thus, in forested lands, the farmer uses the fire only once to have the soil ready for cultivation. Furthermore, there are indications that the 
yields from slash-and-burn agriculture were higher than those obtained from permanent cropping systems, thanks to the mineral nutrients present in the ashes. In a permanent open field, in addition to a higher labor cost to maintain soil fertility, there was the extremely high cost of controlling weeds. An arduous work of mechanical control is necessary to prepare an area invaded by weeds. As Sigaut (1975, p.167) observed, "in the past, the greatest enemy of the farmer were not the trees, but the grass [weeds]." Thus, it would be economically incomprehensible for farmers to abandon the system of shifting cultivation in favor of permanent agriculture if something had not coerced them to do so.

The system of permanent agriculture that replaced the shifting system in Northern Europe became known as the two-year rotation system. The invention of the heavy plow represented a decisive leap. Primarily conceived as an instrument of weed control, it represented the first laborsaving instrument for the field operations in the history of agriculture. In this new permanent culture system, the plot was divided into two parts, and one remained in "fallow", to be sowed in the next season. This period of "fallow" was confused by many authors as a period necessary for the soil recover its fertility, as in the shift cultivation mode except by the length of the fallow period. However, as pointed out by Sigaut (1977), this idea goes against the very etymological meaning of the French word "jachère" for fallow, which means "to work the land" (to control weeds).

Regarding the fertilization of the crops, this represented a significant problem to be solved. In the impossibility of having exogenous sources of nutrients on a significant scale, the fertilization techniques were based on the transfer of organic matter from the surrounding land to the field under permanent cultivation. This transference was done in two ways: either directly, through the collection of vegetation (étrepage), or indirectly, through the intestines of animals. The shortage of forage for the animals available in the fallow plots (crop residues, cut weeds) forced the peasants to complete the cattle feeding by releasing it into the surrounding natural forests and pastures and bringing it back at night to the crop fields ("Parcage de nuit") to take advantage of their nocturnal dejections. The losses of mineral elements were high, especially of nitrogen.

\section{Dynamics of technical change}

The invention of the heavy plow around the 8th century was a technological response to a radical change in the agroecological conditions caused by the change from shifting agriculture to permanent agriculture. However, its fully effective use was limited when pulled by oxen. Horses are a much better option for being faster, although weaker. However, due to the prevailing harnessing system, horses could not be used in full capacity. The invention of the "horse collar", solved the problem displacing the point of support from the horse's neck to the chest (or "shoulders"), alleviating the pressure over the animal's jugular. In this sense, the old harnessing system was, literally, a real "bottleneck" that prevented more efficient use of the new equipment.

White (1962) considers that these combined inventions - the heavy plow and the horse collar - led to an agricultural revolution: replacing the biennial rotation system by the triennial rotation system. The land plot will be divided into three parts: one, as usual, to be sown with a winter cereal (wheat or rye) at the end of autumn; another remained in "fallow"; and, the third, and here is the novelty, to be sown during early spring with a less important cereal to fed humans (oats, barley), but also less demanding from the soil nutrients than wheat. Thus, 
instead of producing in only half of the soil surface each year using the biennial rotation system, the farmer used two thirds of the total area in the triennial rotation system, representing an increase of $34 \%$ of the cultivated surface for the same amount of work.

For the agricultural calendar, these two systems present different working processes. For the old biennial system there were three fazes: sowing winter cereal, controlling weeds in the fallow plot, and harvesting. For the new triennial system there will be five fazes: sowing winter cereal, controlling weeds in the fallow plot, sowing spring cereals crop, and two harvests. For this new calendar of agricultural work to be feasible, the field preparation for planting the spring crop had to be fast; otherwise, there would not be enough time for the grains to mature by the end of the summer. The work is better distributed throughout the agricultural calendar in the new system and more precise and intensive, requiring a set of faster and more powerful soil preparation instruments, which could only be obtained by using the horse as a traction animal. It took centuries for the full spread of the new rotation system in the 13th century. According to White (1962), initially, the established agrarian interests opposed its introduction. However, the Viking invasions of the 9th and 10th centuries left large areas depopulated, which facilitated the adoption of the new system. Then, the stimuli from the favorable climate change that occurred by the end of the millennium and the substantial trade expansion contributed to its spreading.

It is important to note that if it was not possible to adopt the triennial rotation system without horses as heavy-duty animals, however, the reverse was also true, i.e., the significant expansion of the equine herd was only possible because of it. The reason for that lies in the fact that horses are not ruminants; their food must be supplemented with cereals. Under the biennial rotation system, grain production was not large enough to feed humans and horses. The spring crop from the triennial system, especially oats, was used almost exclusively to feed horses. Moreover, the expansion of the equine herd played a decisive role in the development of Europe.

For starters, it stimulated several manufacturing activities to produce the equipment and materials necessary to use the horse efficiently. Among these activities was metallurgy, thanks mainly to horseshoes making: without them, the intensive use of horses would become practically unfeasible. Another factor of significant impact was the use of horses in the transport system, replacing the slow oxen and allowing the emergence of a whole range of types of transport equipment (carts, wagons, carriages, eking etc.) destined to multiple and varied tasks. The improvement of transport capacity, caused multiple positive impacts, starting with those in the agricultural production system itself as, for instance, it made it possible a more systematic application of soil correctives, such as limestone and some types of natural chemical fertilizers.

Moreover, as Mazoyer (1977, p. 31) pointed, without the transport of several tons of fodder, straw, and manure per big animal head per year, housing and feeding the cattle during the winter would not be possible. That was a decisive step to make the production of composted organic fertilizers possible. As mentioned above, the fertilization method until that moment consisted of the transfer of organic matter, directly or indirectly, from the surrounding forests and fields to the cropland. The nutrient losses (nitrogen) were high. Using lairage, taking full advantage of the animals' droppings became possible, composting them to avoid nutrient losses, especially of nitrogen. As a result, the yields per hectare doubled over time, and when compounded to the expansion of a third of the cultivated area with the triennial system resulted in a very significant 
increase in labor productivity. The revolution in the transport caused by horses had even an impact on the geographic distribution of the population, leading to a "villagization" process: better transportation allowed the peasants to live in villages and go every day to their crop fields. The defense of farming communities became easier as the population could concentrate in villages around a church that served as the "house of God and the shelter of men" (as a meeting place, refuge, and even as a barn in cases of exceptional crops) (Bloch,M.1976). The socioeconomic, cultural, and psychological impacts of this process cannot be overestimated.

In short, from the invention of the plow, a whole chain of innovations and improvements can be traced, which developed the infrastructure and the transport capacity of the collectivity, increasing its potential for capital accumulation and giving rise to what Mazoyer (1977) called a "culture d'attelage" (harnessing culture). Braudel (1979) points out, precisely, the extensive use of horses for human and cargo transportation as one of the outstanding features of the dynamism of European civilization, which stands in stark contrast to the superhuman effort required by the transport on the backs of men used massively in other great civilizations like the Chinese and the Hindu. Therefore, the increase of the equine herd represents a better form of, literally, accumulation of capital that is qualitatively distinct from the accumulation based on other types of herds.

This type of technological path is a recurring phenomenon in the history of technical progress, as shown by Rosenberg (1982). As a rule, techniques are not isolated from one another but articulated in a coherent set, so, as one of its components changes, the technological system become imbalanced what, in turn, induces the emergence of new techniques. It can be said so that the movement towards the triennial rotation system was not a result of the demographic pressure, as was supposed by many scholars and its generalization raised the overall productivity of agricultural labor. The new triennial rotation system required no more workers than those already available; it required adequate equipment to work on the soil more quickly. The new mouths to feed were not only those of men, but especially those of horses, these fantastic means of work, transportation, and fearsome weapons of war.

The diffusion of this set of innovations provided the peasants with a highly satisfactory daily food ration, which generally included meat. Thus, it is essential to note that the still prevailing idea, one can say "popular," that the more we go back in time towards the Middle Ages, the deeper the misery, is entirely false. As Braudel (1979, v.I, p.163) observes, the truth is the opposite. The peasantry's living conditions began to deteriorate at the end of the 13th century due to the exhaustion of the agricultural frontier, resulting in almost complete deforestation and aggravated by a new climatic change, this time unfavorable. The privilege of "l'Europe carnivore" (carnivorous Europe), according to Braudel's expression, was only reestablished (for the peasants) with the generalization of the Norfolk four course system over the 18 th and 19 th centuries.

\section{Capital accumulation in agriculture and capitalism}

In addition to the transformative impacts inherent to the type of capital accumulation brought by innovations in feudal agriculture, this accumulation connects with the manufacturing and commercial expansion in the existing institutional/organizational context. The commercial revolution started by the 
Italian cities in the 9th century would not have had the amplitude it had without an equivalent response from the feudal agrarian world. This response implied the progressive reduction of serfdom relationships between peasants and masters in favor of non-servile contractual forms, which always coexisted with the serfdom system but that eventually assumed a preponderant role.

Vilar (1975) observes that the vast international trade only became widespread in the 11th century - when this technological, socioeconomic, and institutional development reached its maturity in terms of production capacity. The international trade, in turn, stimulated the growth of local production and the subsequent substitution of urban handicrafts for rural handicrafts. The capital accumulation resulting from the increase of labor productivity has very different dynamic effects when compared to the capital accumulation resulting just from population growth. The struggle between servants and masters to appropriate the growing agricultural surplus intensified, and the process of social differentiation of the peasantry stimulated, generating a class of agrarian capitalists. The commercial development further impacts the relationship between landlords and serfs as the increasing quantity and diversity of commodities available for the landlords induces a transition from payments in labor or products to payments in money. Landlords also began depending more and more on credit, which accelerated their downfall. The development of cities also accelerated the dissolution of the system, since it increases the bargaining power of servants vis-à-vis the landlords by offering them shelter and labor alternatives. As Kula (1977) stated, the "coefficient of practicable oppression" is reduced for the benefit of the serfs.

It must be kept in mind the fact that European feudalism evolved most of the time in the context of labor shortage, which was counterbalanced by the scarcity of military labor until the 10th century: the situation of extreme insecurity forced the peasants to place themselves under the protection of a warlord. When the significant invasions ceased in the 11th century, the agricultural frontier opened again. Therefore, the value of military labor fell, and the value of agricultural labor increased. Monasteries underwent an enormous expansion during this period as they barely had military protection. The competition for labor was intensified, making it increasingly difficult for a feudal lord to benefit from the rising productivity brought by the flow of innovations.

Serfs deserted numerously and continuously: the exodus of an entire peasant village, or even of a whole county, was not rare when the landlord was too inflexible. For example, in the 12th century, the severity of the landlord pushed the inhabitants of the Isle of Rhé to mass desertion, eventually forcing him to make concessions to retain some workforce. The landlords, for their part, sought to make mutual assistance agreements for the capture of fugitive serfs. However, the "market forces" tended to prevail, and, despite treaties and mutual promises, opportunistic behavior became the norm in active competition to attract and seduce the serfs of the neighboring domains, leading to concessions to the laborers. In many regions of France, these concessions translated into the laborers buying their tilts, which led to the formation of rural communes through village associations which, similarly to the towns, had their town hall and jurisdiction (see Dobb,M.1974, pp.65/66) .

The substituting of payments ("corvée") in work, which characterized the ns classic feudal system, to payments in products and finally in money, represented the first step towards the general emancipation of the serfs, as it had a profound impact on the relations between servants and masters; impersonal and objective relations slowly replaced the personal relations between these two groups. 
Takahashi (1972) observes that the change from payments in labor into payments of a fixed amount of money, as determined by jurisprudence, was also an essential factor in the transformation of feudal relations benefiting the workers, as productivity increased and the currency depreciated with inflation. Some landlords were able to escape from ruin by becoming themselves agrarian capitalists.

\section{Final considerations}

After the fall of the Roman Empire, the new political order that slowly asserted itself in Northern Europe, fragmented into competing feudal states that were also characterized themselves by the fragmentation of power between various institutions and organizations (corporations): the monarchy, feudal aristocracy, Church, independent cities, monasteries, universities and craft corporations. They had in common two distinctive cultural traits: (a) a JudeoChristian worldview, characterized by a linear and progressive conception of time, where nature is a divine creation offered to men, and a dignifying view of labor; (b) the affirmation and prevalence of individualism, as opposed to the predominant familism in other civilizations. This compound of cultural and political factors produced an unprecedented civilizational situation in terms of openness to the incessant introduction of cultural, political, organizational, and technological innovations.

From the economic point of view, one can argue that among the most significant results of the political/institutional and cultural environment that characterized the period was the increase in marginal labor productivity, in sharp contrast with, for example, the case of China. Starting with the main productive sector, agriculture, and livestock, but extending to all others. The great crisis of the 14th century ended the medieval phase in the European evolutionary process, but not its legacy. In the restarting of growth in the 15th century competing centralized territorial states substituted to feudal competition; furthermore, a legacy of a comparatively high level of accumulation of physical capital (especially the capital represented by the vast network of wind and hydraulic mills and the equine herd); and, more importantly, the formation of centralized states did not eliminate fundamental cultural and institutional innovations generated during the medieval period - the Rule of Law, individualism, representative assemblies capable of limiting the power of the States, the respect for professions, the embryo of a culture of progress, of growth.

Thus, although the rise of centralized National States made many of the medieval organizations that had an essential role in the innovative dynamism of this period disappear or mostly lose their autonomy - such as craft guilds, autonomous cities, the Catholic Church itself -, the evolutionary movement driven by Schumpeterian innovations continued and led to the Industrial Revolution in the 18th century. 


\section{References:}

Acemoglu,D.and Robinson,J.A.(2012). Why Nations Fail. The Origins of Power, Prosperity, and Poverty. New York: Crown Publishers. Kindle Edition.

Bloch,M.(1949). La société feodale. La formation des liens de dependence. Paris: Albin Michel.

Bloch,M.(1976). Les caractères originaux de l'histoire rurale française. Paris: Librairie Armand Collin.

Boserup,E.(1970). Evolution agraire et pression démographique. Paris: Flammarion.

Braudel,F.(1979, tome 1). Les Structures du Quotidien. Civilisation materièlle, économie et capitalisme, XVème - XVIIIème siècles. Paris: Librairie Armand Collin.

Braudel,F.(1979, tome2). Les Jeux de l'Echange. Civilisation materièlle, économie et capitalisme, XVème - XVIIIème siècles. Paris: Librairie Armand Collin.

Braudel,F.(1979, tome3). Les Temps du Monde. Civilisation materièlle, économie et capitalisme, XVème - XVIIIème siècles. Paris: Librairie Armand Collin.

Deane,P. and Cole,W.A.(1962). British Economic Growth, 1688-1959. Cambridge University Press.

Dobb,M. (1974). Estudios sobre el Desarollo del Capitalismo. Siglo Veintiuno Argentina Editores S.A.

Dobb,M.(1972). "Replica". In: Do feudalismo ao capitalismo. Lisboa: Publicações Don Quixote.

Dovring,F.(1965). "The transformation of European agriculture". In: Habakkuk,H.J. and Postan,M.(ed.). The industrial revolution and after: income, population, and technological change (II). The Cambridge Economic History, Cambridge at the University Press.

Frank,A.G.(1998). Reorient: Global Economy in the Asian Age. Berkeley: University of California Press.

Fukuyama,F.(2011). The Origins of Political Order. From Prehuman Times to the French Revolution. New York : Farrar, Straus and Giroux.

Gies,F.\&F. (1994).Cathedral, Forge, and Waterwheel. Technology and Invention in the Middle Ages. New York : Harper Collins Publishers.

Gimpel, J.(1975). La révolution industrielle au Moyen Age. Paris : Éditions du Seuil.

Goldstone,J.A.(2009). Why Europe? The Rise of the West in World History, 1500-1850. New York: McGraw-Hill.

Goody,J.(1983). The Development of the Family and Marriage in Europe. New York : Cambridge University Press.

Greif,A.(2006). Institutions and the Path to the Modern Economy. Lessons from Medieval Trade. Cambridge University Press. Kindle Edition.

Hajnal,J. (1965). European marriage patterns in perspective. In Population in History, ed. David Glass and D.E.C. Eversley. London : Edward Arnold.

Hobsbawn,E.(1977). Industry and Empire. The Pelican Economic History of Britain. Vol.3. Penguin Books.

Hobson,J.M.(2004). The Eastern Origins of Western Civilization. Cambridge University Press.

Inikori,J.E.(2002). Africans and the Industrial Revolution in England: A Study in International Trade and Development. Cambridge University Press.

Jones,E.L.(1987). The European Miracle. Environments, economies and geopolitics in the history of Europe and Asia. Cambridge University Press.

Kula,W.(1979). Teoria econômica do Sistema feudal. Lisboa: Presença.

Landes,D.(1998). The Wealth and Poverty of Nations. New York: W.W.Norton \& Company,Inc.

Laurent,R.(1976). "L'Utilisation du sol: la renovation des methods de culture". In: Histoire Économique et Sociale de la France, Tome III, Vol. II. Paris: Presses Universitaires de la France.

Le Goff,J.(1990). "Le travail dans les systems de valeur de l'Occident medieval. In: Hamesse,J. et Muraille-Samaran,C. (Ed.). Le Travail au Moyen Âge. Une approche interdisciplinaire. Textes, Études, Congres, vol.10. IEM/Université Catholique de Louvain.

Lopez,R.(1976). The Commercial Revolution of the Middle Ages 950-1350. Cambridge University Press. Kindle Edition.

Mazoyer,M.(1977). "Evolution et differenciation des systems agricoles d'exploitation de la nature". In: Les hommes et leurs sols, n.1 special du Journal d'Agriculture Tropicale et de Botanique Appliquée, v. 12/3, Avril/Septembre.

McCloskey, D. N. (2006). Bourgeois Virtues. Ethics for an Age of Commerce. The University of Chicago Press.

McCloskey, D.N. (2010). Bourgeois Dignity. Why economics can't explain the modern world. The University of Chicago Press.

McCloskey, D.N. (2016). Bourgeois Equality. How ideas, not capital or institutions, enriched the world. The University of Chicago Press.

Mokyr,J.(1990). The Lever of Riches. Technological Creativity and Economic Progress. Oxford : Oxford University Press.

Mokyr,J.(2010). The Enlightened Economy: An Economic History of Britain 1700-1850. New Haven: Yale University Press. 
Mokyr,J. (2016). A Culture of Growth. The Origins of the Modern Economy. Princeton University Press.

Morris,I.(2010). Why the West Rules - For Now. The patterns of history, and what they reveal about the future. New York: Farrar, Straus and Giroux.

Needham,J.(1969). The Grand Tritation. Toronto: University of Toronto Press.

North,D. and Thomas,R.P.(1973). The Rise of the Western World. A New Economic History. Cambridge at the University Press

North,D.C.,Wallis,J.J.and Weingast,B.R.(2009). Violence and Social Orders. A Conceptual Framework for Interpreting Recorded Human History. Cambridge: Cambridge University Press.

Oxele,O.G.(1990). "Le Travail au XI siècle: réalités et mentalités". In: Hamesse,J. et MurailleSamaran,C. (Ed.). Le Travail au Moyen Âge. Une approche interdisciplinaire. Textes, Études, Congres, vol.10. IEM/Université Catholique de Louvain.

Olson,M.(2000). Power and Properity. Outgrowing capitalist and communist dictatorships. NY: Basic Books.

Parrain,C.(1944). "The Evolution of Agricultural Technique". In: The Agrarian Life of Midle Ages. The Cambridge Economic History, Ed. By J.H. Claphannad E. Power, Cambridge University Press.

Perdue,P.(2005). China Marches West: The Qing Conquest of Central Asia. Cambridge,MA: Harvard University Press.

Pernoud,R.(1980). La femme au temps des Cathédrales. Paris: Éditions Stock.

Pomeranz,K.(2000). The Great Divergence. China, Europe, and the Making of the Modern World Economy. Princeton University Press.

Romeiro,A.R.(2017). História do Crescimento Economico. As Origens Político Culturais da Revolução Industrial. Texto para Discussão no. 312, IE/Unicamp.

Rosenberg,N.(1982). Inside the Black Box: Technology and Economics. Cambridge Univer-sity Press.

Rosenthal,J-L.and Bin Wong,R.(2011). Before and beyond Divergence: The Politics of Economic Change in China and Europe. Cambridge,MA: Harvard University Press.

Schachner,N.(1938). The medieval Universities. New York: Frederick A. Stokes. Apud Stark,R. (2014).pos.3081.

Sigaut,F.(1975). L'Agriculture et le Feu. Role et place du feu dans les techniques de preparation du champ de l'ancienne agriculture europeenne. Paris: EHESS et Mouton and Co.

Sigaut,F.(1977). "Quelques notions de base em matière de travail du sol dans les anciennes agricultures europeennes". In: Les hommes et leurs sols, n.1 special du Journal d'Agriculture Tropicale et de Botanique Appliquée, v. 12/3, Avril/Septembre.

Slicher,Van Bath, B.H.(1966). The Agrarian History of Western Europe, A.D.500-1500. London: E. Arnold Publishers Ltd.

Stark,R.(2014). How the West Won. The Negleted Story of the Triumph of Modernity. Wilmington: ISI Books. Kindle Edition.

Sweezy,P.M.(1972). "Uma critica". In: Do feudalismo ao capitalismo. Lisboa: Publicações Don Quixote.

Takahashi,H.K.(1972). "Uma contribuição para a discussão". In: Do feudalismo ao capitalismo. Lisboa: Publicações Don Quixote.

Usher,A.P.(1954). A history of mechanical inventions. Harvard University Press.

Vilar,P.(1975). "A transição do feudalismo ao capitalismo". In: Santiago, Theo A. (Org). Capitalismo, transição. Rio de Janeiro: Eldorado.

Vries,P.(2015). State, Economy and the Great Divergence. Great Britain and China, 1680-1850s. Bloomsbury Publishing Plc. Kindle Edition.

White,L.(1962). Medieval Technology and Social Change. Oxford University Press.

White.L.(1967). "The Historical Roots of four Ecological Crisis". In: Science, 155. 